\title{
Proposal for the Adaptation of Brazilian Standard ABNT NBR 16274 for Correct Assessment of PV Generator Connected to the Grid with Microinverter
}

\author{
Felipe de Oliveira ${ }^{1}$, Rodrigo Teixeira ${ }^{1}$, Tatiani Pivem ${ }^{1}$, Sandro Petry ${ }^{2}$, Bruna Larissa Spontoni ${ }^{2}$ and Laura de \\ Oliveira $^{1}$ \\ 1. The Department of Research and Development, Nexsolar Soluções em Energia Solar LTDA, Campo Grande, CEP: 79002-450, Brazil \\ 2. The Department of Civil Engineering, Universidade Federal de Mato Grosso do Sul, Campo Grande, CEP: 79070-00, Brazil
}

\begin{abstract}
One of the main promises of solar photovoltaic technology has been the use of so-called microinverter which intends to make it possible for anyone to produce their own power generation. This article presents a discussion of a proposal to adapt the Brazilian Standard NBR 16274 (photovoltaic systems connected to the network-minimum requirements for documentation, commissioning tests, inspection and performance evaluation) of grid-connected photovoltaic (PV) system design methodology-oriented inverter module (or microinverters). The article begins by presenting the different methodologies grid-connected PV system projects discussing positive and negative aspects of each. Then search presents a discussion of the positive and negative aspects of grid-connected PV system design methodology with microinverters, giving a practical example of design. The paper is organized as follows: Section 1 provides an introduction explaining the importance of the proposed methodology; Section 2 presents the different types of grid-connected PV system design methodology as well as its positive and negative aspects; Section 3 describes the key differentiators of grid-connected PV system design methodology with use of microinverters finished with practical example of scaling; Section 4 presents the main proposals to adapt and points on conflict of NBR 16274; Section 5 presents the work's conclusions.
\end{abstract}

Key words: Solar energy, Brazilian standard, microinverter.

\section{Introduction}

One of the main promises of solar photovoltaic (PV) technology has been the use of the so-called microinverters, which intends to make it possible for anyone to generate their own power. Nowadays, it is well known that the application of grid connected photovoltaic systems in Brazil was only considered "viable" for consumers that have a demand above 400 $\mathrm{kWh}$ per month. The marketing for these consumers becomes the central focus of sales. The market distribution, according to Ref. [1], states that the largest number of energy consuming units in Brazil are

Corresponding author: Felipe de Oliveira de Araújo, CEO, research fields: solar energy system, solar cell and power electronics. households, which represents $85 \%$ (63.8 million) of total units, while $7 \%$ are commercial (5.4 million), and only $1 \%$ of these consumers are industrial units (around 584 thousand), out of a total of 74.8 million spread across the country. Clearly the greatest potential is in the residential consumer units, but as mentioned before it is still a market that has difficulties implementing PV systems. If we go deeper into this subject, we can use the criteria defined in Ref. [2], where it is argued that the potential market for residential units would be residences where income exceeds five minimum wages, restricting a market that was previously from 63.8 million to about 25 million. From this market, when analyzing the consumption profile, we have an interesting characteristic: the part that was not considered viable for the application of PV system 
connected to the grid, in Brazil, represents $89 \%$ of the target market. Such an assertion was justified by the application of only two methodologies for the design of grid-connected PV system: central inverters or branch (string oriented inverters), which resulted in a minimum inverter size, a minimum number of photovoltaic modules and, consequently, an investment minimum of $\mathrm{R} \$ 22,000.00$ to $\mathrm{R} \$ 30,000.00$, making the technology considered impractical due to the high initial investment, providing an advantageous return only to a range of consumers who have a consumption of at least $400 \mathrm{kWh} /$ month.

This article presents a discussion of a proposal to adapt the Brazilian Standard ABNT NBR 16274 and some points in some technical standards of several concessionaires for the correct evaluation of the module-oriented inverter grid-connected PV system (or microinverters) methodology. The paper is organized as follows: Section 1 presents a justification for the importance of the proposed methodology; Section 2 presents the different types of methodology design of grid-connected PV system as well as their positive and negative aspects; Section 3 describes the main differentials of methodology of grid-connected PV system with the use of microinverters completed with a practical example of sizing; Section 4 presents the main adaptation proposals and the conflicting points of ABNT NBR 16274; Section 5 presents the conclusions of job.

\section{Design Methods of Grid-connected PV Generator}

The first grid-connected PV system used a single central inverter to connect to the photovoltaic generator. Currently this is not the only possible configuration. It can be classified as follows:

(a) Configuration with central inverter;

(b) Configuration with branch-oriented inverter or sub-generator;

(c) Configuration with inverter oriented to the module (or configuration with microinverters);

\subsection{Low DC Voltage Central Inverter Configuration}

Fig. 1 shows the schematic drawing for this configuration. Among the main advantages presented in this methodology are:

- Greater immunity to partial shading, or loss due to divergence;

- Cables of cabling DC with larger gauge;

- Working with low voltage DC can use class III material for protection;

\subsection{High DC Voltage Central Inverter Configuration}

Fig. 2 shows the schematic drawing for this configuration. Among the main advantages presented in this methodology are:

- Less immunity to partial shadowing, or loss due to divergence

- DC cabling cables with lower gauge;

- Due to the use of DC high voltage, it is necessary to use class II material for protection;

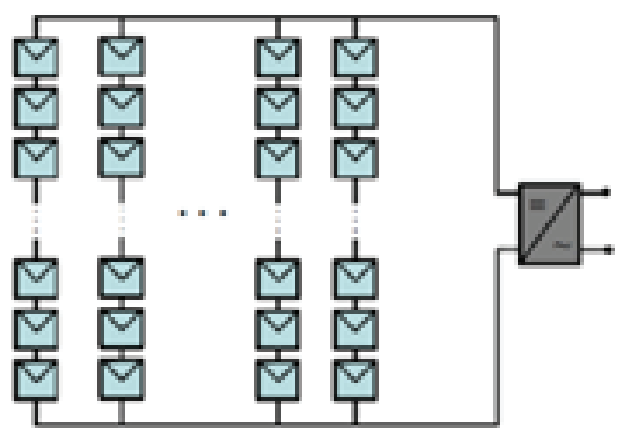

Fig. 1 Design methodology with central inverter with low voltage DC.

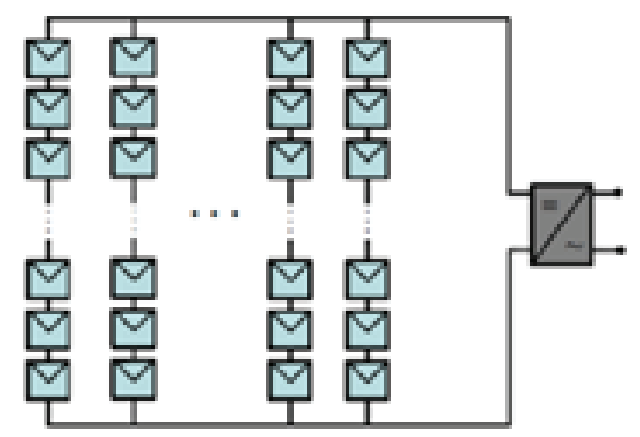

Fig. 2 Design methodology with central inverter with high voltage DC. 


\subsection{Branch Oriented Inverter Configuration or Sub-Generator}

Figs. 2 and 3 present the schematic drawing for this configuration. Among the main advantages presented in this methodology are:

- Greater immunity to partial shading, or loss due to divergence;

- No need for blocking diodes;

- Decreases the cost of DC cabling and the amount of connection DC box;

- When only one inverter fails its installation is still in operation;

- Less immunity to partial shadowing, or loss due to divergence;

- DC cabling cables with lower gauge;

- Due to the use of DC high voltage, it is necessary to use class II material for protection.

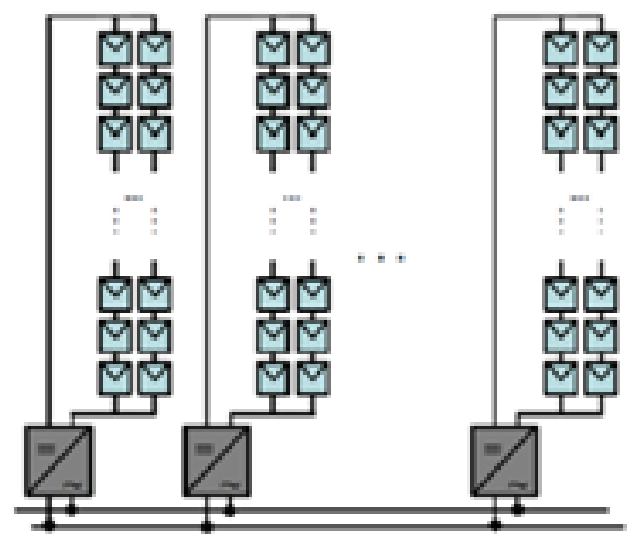

Fig. 3 Design methodology with inverter oriented to branch.

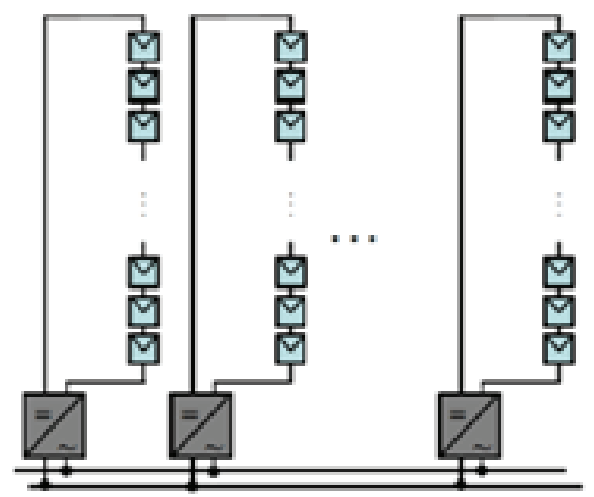

Fig. 4 Design methodology with inverter oriented to sub-generator.

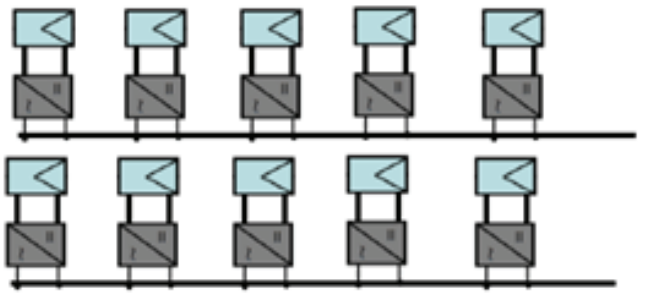

Fig. 5 Design methodology with inverter oriented to PV module or microinverter.

\subsection{Module Oriented Inverter Configuration}

Fig. 5 shows the schematic drawing for this configuration. Among the main advantages presented in this methodology are:

- High immunity to partial shadowing, or loss due to divergence;

- No DC cabling;

- Great modularity.

\section{Microinverters Applied to PV Generator Grid-connected}

When compared to the design methodology of solar photovoltaic systems connected to the grid with the use of central/string inverters, the methodology of microinverters has the following advantages:

- Easy installation: Use of plug \& play technology. The DC circuit is simpler compared to methodology central/string inverter, which minimizes the risk of accidents and errors, allowing easy installation.

- Longer life: The longer life of the microinverters can be justified by the fact that they operate in low power. In this way problems inherent to the design are solved, eliminating the need of a large transformer, as well as large electrolytic capacitors can be replaced by capacitors (Thim Film), not to mention that cooling.

- It produces $25 \%$ more power than systems that use central/string inverter methodologies: An energy production in photovoltaic systems connected with central inverter/string methodology is given by the PV module (photovoltaic) of lower production. While the production of energy in grid-connected photovoltaic systems with micro-inverter methodology is independent for each module [3, 4]. 
- More secure: The use of microinverters prevents faults known as "ARC FAULT", which is one of the main causes that make photovoltaic installations catch fire.

\section{Sizing an Installation Using Microinverters}

The definition of the inverter design methodology oriented to the module (or microinverter methodology) is the single module connection for each inverter with the MPPT algorithm (maximum power search methodology). It is normally permissible to connect $180 \mathrm{~W}-310 \mathrm{~W}$ on each microinverter. Being the maximum voltage and current admissible in its inputs terminals of $55 \mathrm{~V}$ and $12 \mathrm{~A}$ respectively. Some microinverter models have the efficiency of their MPPT algorithms up to $99.5 \%$ while the conversion efficiency reaches $95.6 \%$ according to Ref. [5]. The following subsections describe the steps for designing a microinverter installation.

4.1 Choice of Photovoltaic Module for Each Microinverter

(A) Calculate $V_{\text {oc }}$ (open circuit voltage) of the chosen photovoltaic module for maximum temperature $\left(t(c) \max =70^{\circ} \mathrm{C}\right)$, ensuring that the minimum voltage required for the operation of the MPPT algorithm (MinVin), according to Eq. (1).

$$
\begin{gathered}
\operatorname{Voc}\left(t_{c} \max \right)= \\
\operatorname{Vac}+\frac{\operatorname{Voc}\left(t_{c} \max -t_{3 i e}\right\}^{2} \beta}{100}>\operatorname{MinVin}
\end{gathered}
$$

(B) Calculate $V_{\text {oc }}$ of the photovoltaic module chosen for a lower temperature $\left(t(c) \min =-10{ }^{\circ} \mathrm{C}\right)$, ensuring that it is less than the maximum permissible voltage at the input of the microinverter terminals (MaxVin), according to Eq. (2).

$$
\begin{gathered}
\operatorname{Voc}\left(t_{c} \min \right)= \\
\operatorname{Voc}+\frac{\operatorname{Voc} *\left(s_{s} \sin -t_{s i c}{ }^{3} \%(\%)\right.}{100}<\operatorname{MaxVin}
\end{gathered}
$$

(C) Calculate $V_{\text {mpp }}$ (voltage at maximum power point) of the chosen PV module for maximum temperature $\left(t(c) \max =70{ }^{\circ} \mathrm{C}\right)$, ensuring that it is greater than the minimum voltage required for performance of the MPPT algorithm (MinVmpp), according to Eq. (3).

$$
\begin{gathered}
V m p p\left(t_{\varepsilon} \min \right)= \\
V m p p+\frac{W_{m p p}\left\{t_{r} \max -t_{s i z}\right\}+\beta[0]}{100}>\operatorname{MinVmpp}
\end{gathered}
$$

(D) Calculate $V_{\text {mpp }}$ of the photovoltaic module chosen for lower temperature $\left(t(c) \min =-10{ }^{\circ} \mathrm{C}\right)$, ensuring that it is less than the maximum permissible voltage for the operation of the MPPT (MaxVmpp), according to Eq. (4).

$$
\begin{aligned}
& V m p p\left(t_{c} m i n\right)=
\end{aligned}
$$

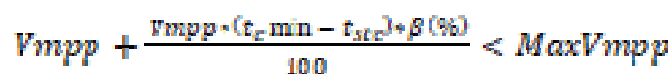

(E) Calculate $I_{\mathrm{sc}}$ (short circuit current) of the chosen $\mathrm{PV}$ module for maximum temperature $(t(c) \max =$ $70{ }^{\circ} \mathrm{C}$ ), ensuring that it is less than the maximum permissible current at the microinverter terminals (Imax), according to Eq. (5).

$$
\begin{gathered}
\operatorname{Isc}\left(t_{c} \max \right)= \\
I s c+\frac{\operatorname{lsc}\left(t_{c} \operatorname{sax}-t_{5 s z} \sec ^{3}(\%)\right.}{100}<\operatorname{Imax}
\end{gathered}
$$

\subsection{Sizing of Photovoltaic Generator Cabling}

The sizing of the conductors of a photovoltaic generator with a central inverter/string was divided into two parts: one responsible for carrying the direct current produced by the photovoltaic modules (DC cabling) and another party responsible for carrying the alternating current converted by the photovoltaic inverter (AC cabling). When designing a photovoltaic generator that contains only microinverters, the voltage drop and requirements with regard to DC cabling are much smaller and often negligible since microinverters are installed below the modules as shown in Fig. 6 . When installing a photovoltaic generator based on microinverters, cabling can be divided into following parts: DC cabling, AC cabling (alternating current) per phase and AC main cabling being DC cabling and AC cabling per phase, often provided by the microinverter itself. Fig. 3 shows a functional scheme of the cabling 


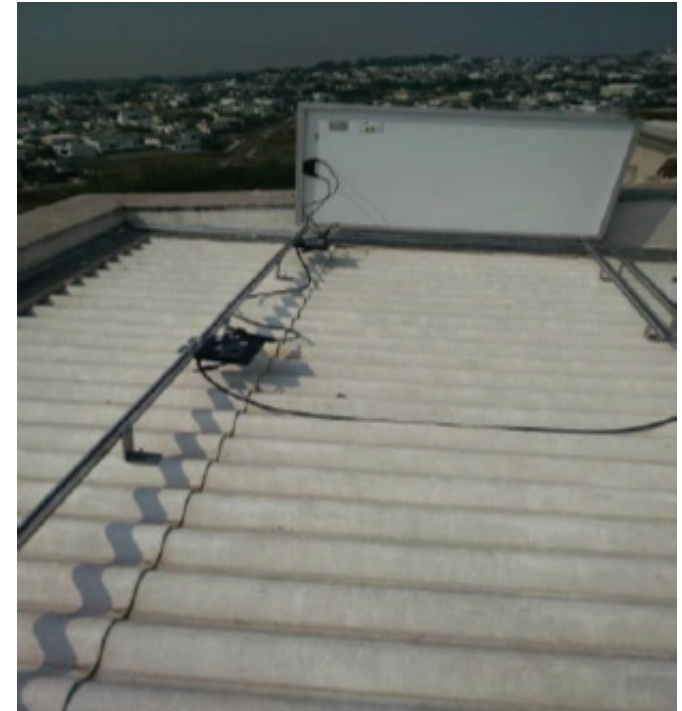

Fig. 6 Installation of microinverters.

parts of a photovoltaic generator with microinverter. By NBR 5410 [6] it is recommended that the maximum value of voltage drop verified between the installation point of the photovoltaic system and the input pattern does not exceed 3\%. To size and verify the correct sizing of cable the design of the conductors is based on the voltage drop and thermal criteria (maximum short current circuit). As with some microinverters, already has DC cabling and AC cabling per $4 \mathrm{~mm}^{2}$ phase we can verify using the voltage and thermal drop criteria that there is a maximum number defined by branch ranging from 3 microinverters for the version that works at $127 \mathrm{~V}$ and of 5 microinverters for the version that works at $220 \mathrm{~V}$ limited by the maximum permissible current of the cabling which is already manufactured and installed on the product.

\section{Proposals for Adaptation in NBR 16274}

\subsection{Discrepancies in NBR 16274}

NBR 16274 [7] establishes the minimum information and documentation that must be compiled after the installation of a photovoltaic system connected to the grid, as well as the commissioning tests and the necessary to evaluate the safety of the installation and correct operation of the system. Among the tests which are to be carried out can be divided into two main categories: (a) Category 1 - set standard to be applied to all systems; (b) Category 2-expanded assumes that all category 1 tests have already been performed. It turns out that as the project design methodology module-oriented inverter does not have access to the DC cabling, which is non-existent, some procedures need to be adapted or even withdrawn for the correct evaluation of this methodology. The next sections discuss the procedures for Category 1 and Category 2 trials that should be adapted.

\subsection{Category Test 1}

A 1-series test protocol is the minimum sequence of tests to be applied to all systems, regardless of scale, type, location or complexity. According to Ref. [7], Category 1 tests are:

5.2.1 Continuity of Earthing and/or Connection Leads

For this test it is required that the photovoltaic generator has its grounded structures as well as each branch of microinverters. It turns out that microinverters are installed directly below each module, being trapped the grounding of the structure. The function of grounding in photovoltaic installations is intended to protect the user from electric shock, either in direct current or alternating current, as well as guarantee equipment equipotentialisation and modules in case of atmospheric discharge. The connection between the DC circuit conductor and the grounding system, in a PV array with microinverters, is done through the Ground Fault Protection Device (GFPG) inside the microinverter. The GFPG plays the role of connecting the system to Earth. The presence of this system requires, in accordance with UL Standard 1741 [8], that the inverter has clearly marked the connection of the conductor and the grounding electrode. Spanish standards as the ITC-BT 24 [9] and 26 [10] say if the open circuit voltage Voc of the PV generator is less than $75 \mathrm{~V}$ is not required have additional protection against voltage from direct or indirect contacts. This way is only requiring that a cable goes through all 
microinverters in its GFPG and goes until the panel of distribution of the residence.

\subsubsection{Polarity Test}

NBR 16274 [7] requires that the polarity of all DC cables is checked. In the design using microinverters there is no connection of modules in series or in parallel, its design being simplified this test becomes simpler. It is only necessary to test the polarities only of the $(+)$ and $(-)$ cables of each module.

\subsubsection{Testing of the Junction Box(es)}

A single photovoltaic series connected with inverted polarity inside a junction box may be difficult to identify. The consequences of a photovoltaic series connected with inverted polarity, particularly in larger systems, with several interconnected junction boxes, may be significant according to Ref. [7]. It turns out that in photovoltaic generators that use inverters oriented to modules (microinverters) is not used junction box. That way you cannot do this test.

5.2.4 Current Tests of the Photovoltaic Series(s) (Short-Circuit or Operational)

The purpose of a current measurement test of a photovoltaic array is to verify that there is no photovoltaic array wiring. These tests cannot be taken as a measure of module/PV arrangement. There are two test methods (short circuit or operational), and both will provide correct operation of the PV series. Where possible, the short-circuit test is as it should exclude any influence of the inverters according to Ref. [7]. The only adaptation that must be made is that as the photovoltaic generator with microinverters does not have serial modules (or string of modules) each module being connected directly to its microinverter the measurement becomes much simpler and safer.

5.2.5 Open Circuit Voltage Tests of Photovoltaic Series(s)

The purpose of the open circuit voltage measurement within the test sequence test sequence category 1 is to verify that the series of modules are correctly connected and, specifically, if the expected number modules are connected in series according to
Ref. [7]. Forgetting an interconnection or interconnecting mistakenly a wrong number of modules within a photovoltaic series is a relatively common error, specifically in larger systems, and the open circuit voltage test quickly identifies these faults. As in the methodology of projects that uses microinverters, there are no modules in series or in parallel this error becomes impossible. Therefore, it is no longer necessary to carry out this test on photovoltaic generators with microinverters.

\subsubsection{Functional Tests}

According to Ref. [7] the functional tests to be performed are: (a) tests on sectioning devices and other control devices in a way that can guarantee that work properly and are properly assembled and counted. In the inverter design methodology, the microinverters are connected to each other, forming a "branch", and are connected to the through a circuit breaker. The circuit breaker basically has the function of interrupting the circuit in front of some circumstance, such as: short-circuit overcurrent, over-current overload or even some maintenance. Different from the central/string inverter design methodology that have several sectioning devices like e.g. Circuit Breaker, Fuses, Switching Switch DC, SPD on both side the DC and $\mathrm{AC}$ in the microinverters methodology this test becomes much simpler. In test (b) all the inverters that are part of the photovoltaic system must be tested to ensure correct operation. The procedure must be defined by the manufacturer. Normally microinverters have operating indication LEDs, or even can be of monitoring units.

5.2.7 Insulation Resistance Test of the DC Circuit(s)

The DC circuit of photovoltaic arrangements is alive during the day, unlike a conventional AC circuit, cannot be isolated before performing this test. Thus, the test must be carried out with clothing and protection. The inverter methodology oriented to the module minimizes the risks of carrying out these tests. According to Ref. [7] there are two possible test methods: (a) test method 1-test between the 


\section{Generator Connected to the Grid with Microinverter}

photovoltaic array and ground, followed by a positive-to-ground test; (b) test method 2-test between the earth and the positive and negative short circuit of the photovoltaic array. The method that makes it easier to test method 1 for installations with microinverters because, as the support structure is earth, the ground connection may be at any suitable ground point or in the PV array structure (when this is used, a good contact must be ensured that there is continuity throughout the entire metallic structure). The Minimum values of insulation resistance measured shall be in accordance with Table 1 of Ref. [7] on page 17.

\subsection{Category Test 2}

A 2-series test protocol is intended for larger or more complex systems. All Test Regimen 1 have been performed, and their associated results before the first of the trials of the category 2 scheme. According to Ref. [7] Category 2 tests are:

\subsubsection{I-V Curve Test of Photovoltaic Series}

When using the inverter design methodology oriented to the module, one should forget the concept of "series" PV modules or "strings". But to carry out the test to know if the measurement of the IV curve and the parameters of Voc and Isc are in agreement with that stated in the datasheet of the of each PV module individually. In addition, it can identify if there are cells short-circuited by-pass diodes, the presence of excessive parallel resistance in cells, or resistance in excessive series. Localized shading and parameter mismatch between modules cannot be more identified by this test as in central inverter/string methodology. It is now necessary to use monitoring equipment (or datalogger) to monitor each module's real-time production to identify these errors.

\subsubsection{Infrared Camera Inspection}

The purpose of an infrared (IR) inspection is to detect abnormal modules in operation in the field. Such temperature variations may indicate problems within the modules and/or photovoltaic arrangements such as reverse polarized cells, by-pass diode failure, solder, bad connections and other conditions that lead to high temperatures located during the operation. This test for photovoltaic generators with microinverters must include another function of monitoring the operating temperature of the micro-inverters that are located below the photovoltaic modules. Microinverter manufacturers say that maximum internal temperature normally ranges from $-40{ }^{\circ} \mathrm{C}$ to $+85{ }^{\circ} \mathrm{C}$. It is very important to identify which average operating temperature of the microinverters, as it influences the efficiency and the useful life of the equipment.

\section{Conclusion}

This article presented a discussion of a proposal to adapt the Brazilian Standard ABNT NBR 16274 for the correct evaluation of the module-oriented inverter (grid-connected PV system microinverters). The main result sought in this work is to show that when evaluating a PV generator connected to grid with module-oriented inverter (or microinverters) a new understanding new philosophy of the DC circuit is necessary that becomes practically nonexistent. Thus, certain aspects, tests and protection that were considered mandatory are no longer useful or end up being considered unnecessary. Another important fact to be concluded is that, with this methodology, it became more accessible to a larger number of consumers in Brazil to install PV connected to the grid, including consumers consuming less than 400 $\mathrm{kWh} /$ month due to the low initial investment cost. Localized shading and parameter mismatch between modules cannot be more identified by this test as in central inverter/string methodology. It is now necessary to use monitoring equipment (or datalogger) to monitor each module's real-time production to identify these errors.

\section{References}

[1] Empresa de Pesquisa Energética (EPE). 2014. "2014 Statistical Yearbook of Electricity 2013 Baseline Year." Rio de Janeiro.

[2] Empresa de Pesquisa Energética (EPE). 2014. "Serie de 

Generator Connected to the Grid with Microinverter

Recursos Energéticos-Nota Técnica DEA 19/14 - Inserção da Geração Fotovoltaica Distribuída no Brasil - Condicionantes e Impactos.” Rio de Janeiro.

[3] Lee, D. M., and Raichle, B. W. 2012. "A Side-by-Side Comparison of Micro and Central Inverters in Shaded and Unshaded Conditions." World Renewable Energy Forum, Denver, USA.

[4] Lee, D. M. 2011. "A Direct Comparison between a Central Inverter and Microinverters in a Photovoltaic Array." Thesis of Master of Science, Appa Lachian State University, University of Virginia, EUA.

[5] Dominic, J. C. 2014. "Comparison and Design of High Efficiency Micro Inverters for Photovoltaic Applications." Thesis of Master of Science, Virginia Polytechnic Institute and State University, USA.
[6] Associação Brasileira de Normas Técnicas. 2008. "Eletrical installations of buildings-Low voltage." ABNT NBR 5410. ISBN: 978-3-16-148410-0.

[7] Associação Brasileira de Normas Técnicas. 2014. "Sistemas fotovoltaicos conectados á rede-Requisitos mínimos para documentação, ensaios de comissionamento, inspeção e avaliação de desempenho.” ABNT NBR 16274.

[8] UL Standard 1741. 2001. "Inverters, Converters, and Controllers for Use in Independent Power Systems." UL Standard.

[9] ITC-BT-24. 2002. del Reglamento electrotecnico para baja tension aprobado por Real Decreto842/2002, de 2 de August. BOE num. 224 de 18 de September de 2002.

[10] ITC-BT-26. 2010. Instalaciones Interiores en Viviendas, Prescripciones Generales de Instalacion. 